\title{
Pollen Morphology of an Endangered, Endemic Anatolian Species, Noccaea aghrica (P.H.Davis \& Kit Tan) M.Fırat \& Özüdoğru (Brassicaceae)
}

\section{Tehlike Altındaki Endemik Noccaea Aghrica (P.H.Davis \& Kit Tan) Fırat \& Özüdoğru (Brassicaceae) Türünün Polen Yapısı}

\author{
Research Article
}

\section{Ali Savaş Bülbül1*, Mehmet Fırat², Burcu Tarıkahya-Hacıoğlư ${ }^{3}$}

'Department of Molecular Biology and Genetics, Faculty of Science, Bartın University, Bartın, Turkey.

${ }^{2}$ Department of Biology Education, Faculty of Education, Van Yüzüncüyıl University, Van, Turkey.

${ }^{3}$ Central Research Institute for Field Crops, Republic of Turkey Ministry of Food Agriculture and Livestock, Ankara, Turkey.

\section{A B S TR AC T}

\begin{abstract}
The material of this study is Noccaea aghrica Fırat \& Özüdoğru, an endangered, endemic species, only known from three localities in eastern Turkey. The pollen grains of $N$. aghrica are usually prolate, isopolar, trizonocolpate, reticulate, and with the colpi almost running the full length and terminating at the poles. The average length and width of the pollens are $16.89 \mu \mathrm{m}, 6.21 \mu \mathrm{m}$ and for polar and equatorial axes are $20.94 \mu \mathrm{m}$ and 18.89 $\mu \mathrm{m}$, respectively. The pollen measurements and scanning electron microscope, light microscope photographs were given in the manuscript.
\end{abstract}

\section{Key Words}

Noccaea aghrica, Brassicaceae, pollen.

\section{ÖZET}

\begin{abstract}
A raştırmamıza konu olan Noccaea aghrica Fırat \& Özüdoğru türü ülkemizde endemik tehlike altında bir tür Aolup yalnızca üç lokalitede bilinmektedir. N. aghrica polenleri genellikle prolat, izopolar, trizonokolpat, retikülat yapıda olup, kolpus neredeyse kutba kadar uzanır. Polenlerin ortalama boy ve eni sırasıyla $16.89 \mu \mathrm{m}$ ve $6.21 \mu \mathrm{m}$; ortalama polar ve ekvatoral eksen boyu ise $20,94 \mu \mathrm{m}$ ve $18,89 \mu \mathrm{m}$ olarak ölçülmüştür. Polen ölçüm sonuçları, elektron mikroskobu ve ışık mikroskobu fotoğrafları da çalışmamızda yer almaktadır.
\end{abstract}

\section{Anahtar Kelimeler}

Noccaea aghrica, Brassicaceae, polen.

Article History: Received: Jun 22, 2015; Revised: Dec 20, 2015; Accepted: Mar 20, 2016; Available Online: Apr 1, 2016.

DOI: $10.15671 /$ HJBC.20164417575

Correspondence to: A.S. Bülbül; Dep. of Mol. Biol. and Gen., Faculty of Science, Bartın University, Bartın, Turkey. 


\section{INTRODUCTION}

The genus Noccaea Moench has approximately 50 species in Turkey. The material of our study, Noccaea aghrica (P.H.Davis \& Kit Tan) M.Fırat \& Özüdoğru, was transferred from the genus Thlaspi L. to Noccaea by Firat et al. [1]. This generic replacement was mainly based on molecular, morphological investigations and seed coat anatomy. N. aghrica (Figures 1,2 ) is an endangered (EN), endemic species, only known from three localities in Turkey. The distribution area of the species is Van and Hakkari regions [1].

Earlier palynological studies in the Brassicaceae concluded that the family is stenopalynous in pollen size and morphology [2]. However, the tribe Physarieae has 4-10-colpate instead of the tricolpate pollen characteristic of the rest of the family $[3,4]$.

The aim of our research is to provide palynological information of this rare endemic Anatolian species, that may be an important tool for plant taxonomists in future works.

\section{MATERIALS and METHODS}

Pollen slides were prepared the with technique of Wodehouse [5] and photographed by the Leica DM 750 digital imaging system. Colpus length and width, pollen shape, exine and intine thickness, and polar and equatorial axes of pollens were measured from at least 30 pollen grains. The terminology for pollen morphology followed Punt et al. [6].

For electron microscopy, pollen grains were mounted on stubs, coated with gold, and examined with a FEl Quanta FEG 450 model scanning electron microscope in Bülent Ecevit University Science and Technology Research Center.

\section{RESULTS and DISCUSSION}

Noccaea aghrica pollens (Figures 3,4,5) are usually prolate-spheroidal, isopolar, trizonocolpate, reticulate, and with the colpi almost running the full length and terminating at the poles. The colpi are usually widest at the equator and gradually narrowing towards the poles. The average length and width are $16.89 \mu \mathrm{m}$ and $6.21 \mu \mathrm{m}$, respectively. The lumina

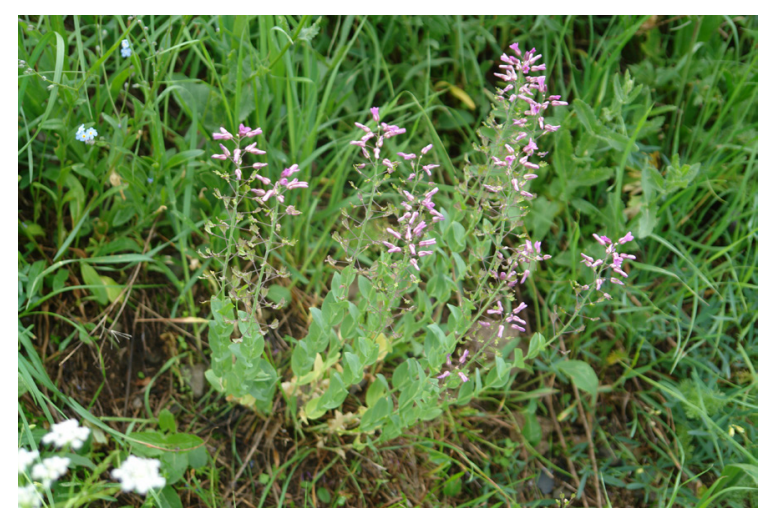

Figure 1. Noccaea aghrica habit.

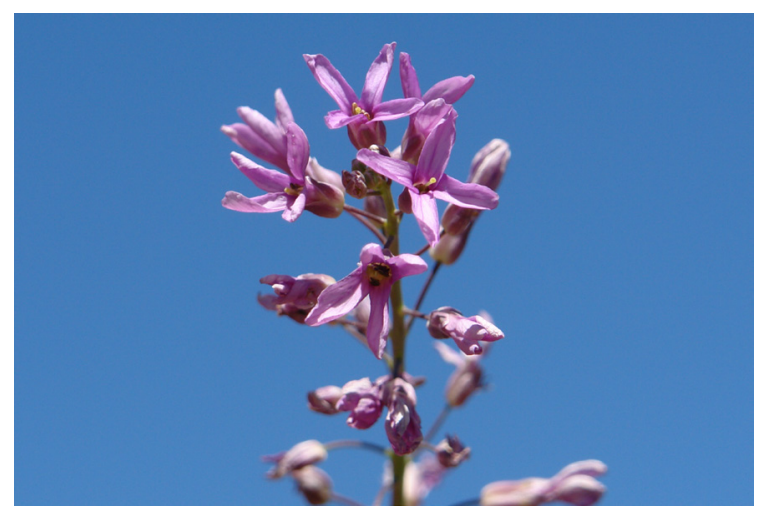

Figure 2. Noccaea aghrica inflorescens.

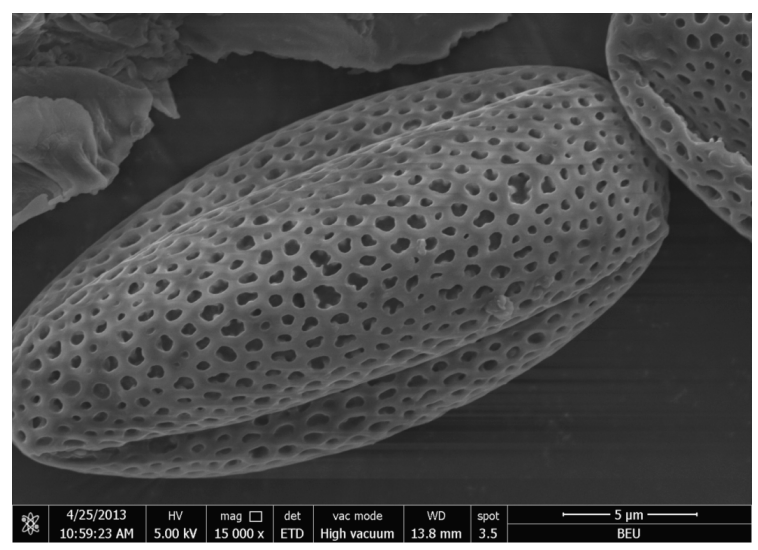

Figure 3. SEM microphotography of Noccaea aghrica pollen.

varied from 4- to 6-polygonal or were irregular in shape. The muri are simplicolumellate and are narrower than the lumina. The average lengths for polar and equatorial axes are $20.94 \mu \mathrm{m}$ and $18.89 \mu \mathrm{m}$, respectively. The average thickness is $1.67 \mu \mathrm{m}$ for the exine, $0.994 \mu \mathrm{m}$ for the lumina, and $0.35 \mu \mathrm{m}$ for the muri (Table 1). 


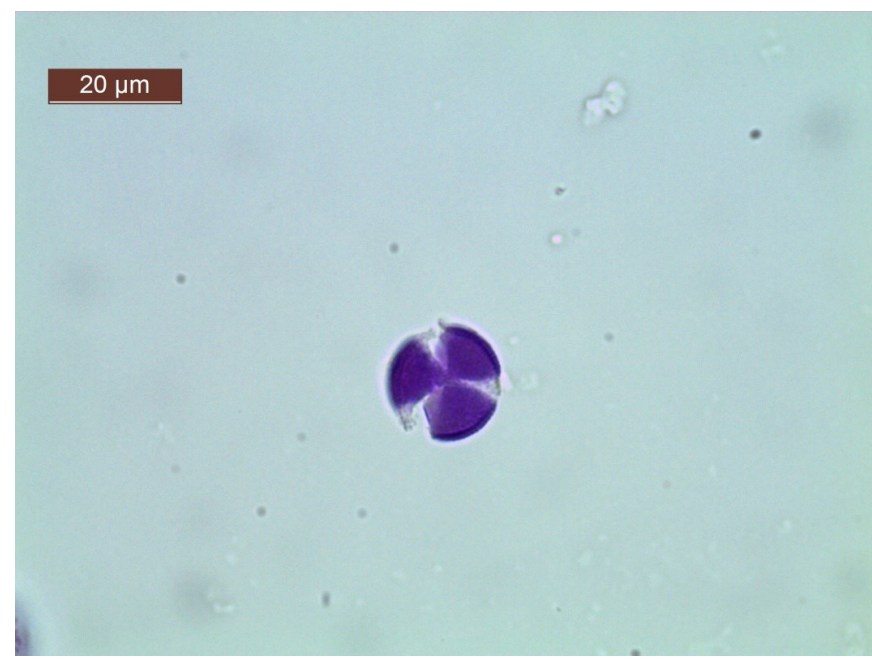

Figure 4. Light microscope image of Noccaea aghrica pollen polar view.

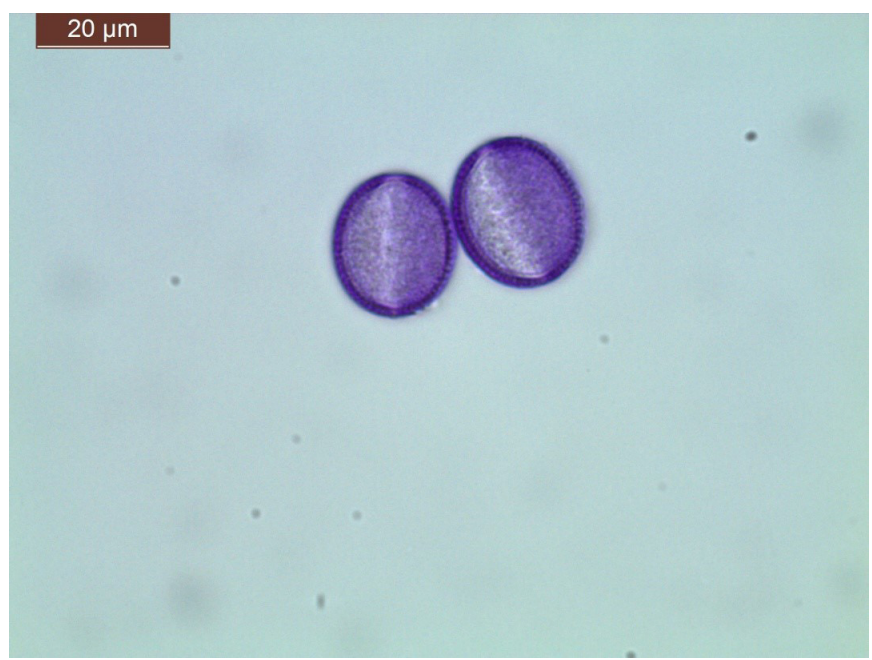

Figure 5. Light microscope image of Noccaea aghrica pollen equatorial view.

Table 1. Pollen measurements of Noccaea aghrica.

\begin{tabular}{ccc}
\hline & Range & Mean/Standard deviation \\
Average diameter of lumina $(\mu \mathrm{m})$ & $0.87-1.10$ & $0.994 \pm 0.54$ \\
\cline { 2 - 3 } Average diameter of muri $(\mu \mathrm{m})$ & $0.30-0.40$ & $0.35 \pm 0.46$ \\
\hline Polar axis $(\mu \mathrm{m})$ & $24.01-17.05$ & $20.94 \pm 1.29$ \\
\hline Equatorial axis $(\mu \mathrm{m})$ & $21.01-17.00$ & $18.89 \pm 0.927$ \\
\hline Exine thickness $(\mu \mathrm{m})$ & $2.01-1.35$ & $1.67 \pm 0.184$ \\
\hline Intine thickness $(\mu \mathrm{m})$ & $0.915-0.412$ & $0.74 \pm 0.134$ \\
\hline Apocolpium $(\mu \mathrm{m})$ & $4.776-2.216$ & $3.85 \pm 0.58$ \\
\hline Mesocolpium $(\mu \mathrm{m})$ & $10.98-9.01$ & $9.77 \pm 0.51$ \\
\hline Colpus length $(\mu \mathrm{m})$ & $19.174-14.111$ & $16.89 \pm 1.54$ \\
\hline Colpus latitute $(\mu \mathrm{m})$ & $6.212-3.0002$ & $4.84 \pm 0.93$
\end{tabular}


We observed only slight differences in pollen size between $N$. aghrica and related species particularly in the polar and equatorial values [7]. In N. aghrica pollen (Figure 4), the average polar and equatorial axes were $20.94 \mu \mathrm{m}$ and 18.89 $\mu \mathrm{m}$, respectively (Table 1 ), whereas in $T$. jaubertii Hedge, the values were $19.7 \mu \mathrm{m}$ and $17.7 \mu \mathrm{m}$, respectively. Also the polar and equatorial axes in Microthlaspi perfoliatum were $19.5 \mu \mathrm{m}$ and 17.6 $\mu \mathrm{m}$, respectively. The palynological properties of $N$. aghrica match the general characteristics of Brassicaeae pollens with trizonocolpate pollen grains.

\section{Acknowledgments}

The authors would like to thank Bülent Ecevit University Science and Technology Research Center for Scanning electron microscopy investigations and to Barış Özüdoğru for scientific comments on the species.

\section{References}

1. M. Fırat, B. Özüdoğru, B. Tarıkahya-Hacıoğlu, A.S. Bülbül, I.A. Al-Shehbaz, K. Mummenhoff, Phylogenetic position and taxonomic assignment of Thlaspi aghricum P.H. Davis \& K. Tan (Brassicaceae), Phytotaxa, 178 (2014) 287-297.

2. G. Erdtman, Handbook of Palynology: MorphologyTaxonomy-Ecology, An Introduction to the Study of Pollen Grains and Spores, Copenhagen: Munksgaard, (1969).

3. R.C. Rollins, U.C. Banerjee, Pollens of the Cruciferae, Publ. Bussey Institution, Harvard University, (1979) 33-64.

4. I.A. Al-Shehbaz, M.A. Beilstein, E.A. Kellogg, Systematics and phylogeny of the Brassicaceae: An overview, Plant Systematics and Evolution, 259 (2006) 89-120.

5. R P. Wodehouse, Pollen grains, McGraw Hill, New York, 1935.

6. W. Punt, P.P. Hoen, S. Blackmore, S. Nilsson, A. Le Thomas,. Glossary of pollen and spore terminology, Review of Palaeobotany and Palynology, 143 (2007) 1-81.

7. Ö. Inceoğlu, F. Karamustafa, The pollen morphology of plants in Ankara Region II. Cruciferae, Communications de la Faculté des Sciences de I'Université d'Ankara, Series C2, 21 (1977) 111-128. 